\title{
Antagonism between fungicide-insecticide treatments and dietholate in irrigated rice seeds ${ }^{1}$
}

\author{
Tiago Viegas Cereza ${ }^{2}$, Filipe Selau Carlos ${ }^{3}$, Claudio Ogoshi ${ }^{4}$, \\ Flavia Miyuki Tomita ${ }^{3}$, Gustavo Campos Soares ${ }^{3}$, André da Rosa Ulguim*
}

\begin{abstract}
The plant safener dietholate can be used for seed treatments (ST) to improve the selectivity of clomazone in rice cultures, thus allowing the application of higher dosages of this herbicide. The objective of this research was to evaluate the interaction between seed fungicide-insecticide treatments with and the plant safener dietholate in irrigated rice. Three experiments were carried out, and the first of them was conducted in a laboratory, following a completely randomized experimental design with four replications. Different ST and treatment-to-sowing intervals were evaluated. The second and third experiments were performed in field conditions, in a completely randomized block design with four replications. In experiment two, seeds were treated with different fungicides, in association or not with dietholate; while in experiment three, the effect of the ST with fungicides and dietholate with clomazone application were assessed. The results evidenced that the association between carboxin + thiram + dietholate reduced seed germination, vigor, and the dry mass of shoot of rice plants. The longer it takes between ST and sowing, the more rice seed germination is negatively affected. The association between fungicides and dietholate may have been antagonistic, and thus interfered with the culture growth potential.
\end{abstract}

Index terms: fungicide, carboxin+thiram, Oryza sativa L., clomazone, safeners.

\section{Antagonismo entre tratamentos com inseticidas, fungicidas e dietholate em sementes de arroz irrigado}

\begin{abstract}
RESUMO - Para proporcionar maior seletividade do herbicida clomazone à cultura do arroz, pode-se utilizar o protetor dietholate em conjunto com outros tratamentos de sementes (ST), o que possibilita o uso de doses maiores do herbicida. O objetivo do trabalho foi avaliar a interação entre o tratamento de sementes que utilizam fungicidas e inseticidas e o protetor dietholate em arroz irrigado. Foram realizados três experimentos, sendo que o primeiro foi conduzido em laboratório, em delineamento experimental inteiramente casualizado com quatro repetições. Neste caso, testou-se diferentes ST e intervalo em dias entre o tratamento de sementes e a semeadura. O segundo e o terceiro experimentos foram realizados em campo, seguindo um delineamento experimental de blocos casualizados com quatro repetições. No experimento dois, foram testados diferentes fungicidas nos ST com ou sem a adição de dietholate; enquanto no experimento três avaliou-se o efeito dos ST com fungicidas e dietholate, quando aplicados juntamente com clomazone. Os resultados evidenciaram que a associação carboxin + thiram + dietholate reduziu a germinação, o vigor de sementes e a matéria seca da parte aérea de plantas de arroz irrigado. O aumento no tempo entre o ST e a semeadura reduziu a germinação de arroz. A associação de fungicidas em combinação com dietholate no ST pode ter ação antagônica e interferir no estabelecimento da cultura.
\end{abstract}

Termos para indexação: fungicida, carboxin+thiram, Oryza sativa L., clomazone, protetores.

\section{Introduction}

Rice (Oryza sativa L.) is considered one of the most

${ }^{1}$ Submitted on 01/23/2018. Accepted for publication on 10/17/2018.

${ }^{2}$ Departamento de Agronomia, Universidade Luterana do Brasil, 92425-900 -

Canoas, RS, Brasil.

${ }^{3}$ Instituto Rio Grandense do Arroz-EEA, 94930-030 - Cachoeirinha, RS, Brasil. important food, once it constitutes the base of diet for more than three billion people (SOSBAI, 2016). Nowadays, rice crops are planted over around 168 million hectares worldwide,

${ }^{4}$ Empresa de Pesquisa Agropecuária e Extensão Rural de Santa Catarina (EPAGRI), 88034-901 - Caçador, SC, Brasil.

${ }^{5}$ Departamento de Defesa Fitossanitária, Universidade Federal de Santa Maria, 97105-900 - Santa Maria, RS, Brasil.

*Corresponding author <andre.ulguim@ufsm.br> 
thus being the second most cultivated cereal, with an annual production of 741 million tons (SOSBAI, 2016). Brazil places among the ten biggest rice-producing countries (EPAGRI, 2017), and it harvested approximately 13 million tons in 2016/2017 (CONAB, 2017). Within the country, the states of Santa Catarina (SC) and Rio Grande do Sul (RS) together respond for $76 \%$ of the national production. Rio Grande do Sul alone accounts for $67 \%$ of it, with a total cultivated area of 1.1 million hectares and an average yield of about 8 tons. ha-1 (IRGA, 2018).

A yield-limiting factor in irrigated rice is the competition with weeds for environmental resources (SOSBAI, 2016). The intensive use of the monoculture system in low lands has contributed for increasing the weed population and elevating the resistance to herbicides. Cases of increased resistance have already been reported for troublesome plants that occur in irrigated rice crops in Brazil, such as weedy rice (Oryza sativa), sedges (Cyperus difformis and Cyperus iria), grasslike fimbry (Fimbristylis miliacea), California arrowhead (Sagittaria montevidensis), and common barnyard grass (Echinochloa crus-galli) (Heap, 2017).

Among the several forms of controlling weeds, the chemical method is largely employed by farmers, either as a pre- or post-emergence treatment. Clomazone is a preherbicide used before rice emergence, which oxidizes and produces 5-keto clomazone (Ferhatoglu et al., 2005). This compound represents the herbicide active-principle and inhibits the enzyme deoxy-xylulose-5-phosphate synthase (DXS), responsible for the isopentenyl pyrophosphate (IPP) synthesis route of the methylerythritol 4-phosphate (MEP) pathway. IPP is an important precursor involved in the biosynthesis of carotenoids in plants (Ferhatoglu and Barret, 2006). Sensitive plants that have been exposed to this chemical suffer from leaf bleaching due to loss of the green color (Senseman, 2007).

Important factors for clomazone selectivity are connected either with the cultivars or the dosages applied (Sherder et al., 2004). An alternative to boost the selectivity of this herbicide is the use of plant safeners, which increase the tolerance of the culture of interest, without reducing the weed control activity (Oliveira Junior and Inoue, 2011). The seed safener dietholate is used in rice plantations because it inhibits the cytochrome P-450 monooxygenase enzyme complex, which is responsible for the oxidation of clomazone in the mesophyll cells (Ferhatoglu et al., 2005). In regular conditions, the cytochrome P-450 monooxygenase works as a detoxication agent in plants; however, when clomazone is present, this enzyme complex causes its activation (Ferhatoglu et al., 2005; Yun et al., 2005).

Usually, rice seed treatment aims at controlling phytopathogens and insects, so that the crop can establish in the field. It must also be able to control soil-associated pathogens, fungi that grow during storage, and phytopathogens that attack in early crop stages. Thus, seed treatment is fundamental to assure the plant stand formation and a high yield (Menten and Moraes, 2010). However, there is not enough information on the possible interactions between fungicide-insecticide treatments and the safener dietholate. Also, little is known about factors related to the exposure time of seeds to the chemical treatment, which may pose a risk during storage due to phytotoxicity buildup (Menten, 1996).

A phytosanitary treatment of seeds is crucial for preventing diseases and insect infestation and, in many situations, it is performed by the joint application of dietholate. On that account, this study aimed at evaluating the interaction between seed fungicide-insecticide treatments and the chemical safener dietholate in irrigated rice.

\section{Material and Methods}

The study consisted of laboratory and field experiments divided into three parts and conducted between 2015 and 2017.

\section{Laboratory experiment (Experiment 1)}

The first experimental step was carried out from September 2015 to March 2016. It included the analysis of effects of different treatments on germination and vigor of rice seeds. For the trials, the cultivar IRGA 424 RI was chosen, and the tests were performed according to a completely randomized design, with four replications of 100 rice seeds. The seeds were sown in paper rolls that had been moistened with distilled water, in a 2-time the dry paper weight ratio. Then, the rolls were kept inside germinator set at an average temperature of $25^{\circ} \mathrm{C}$ for 12 days, until the moment to perform the germination count (Brasil, 2009).

The procedures were arranged in a factorial scheme, in which the factor A comprised the seed treatments (ST), as described in Table 1, and factor B included the intervals between the treatments and the sowing date. The levels considered in factor B were $0,29,60,120$, and 210 days after treatments (DAT). The previously mixed products were applied to the seeds at a relative volume of slurry of $18 \mathrm{~mL}$ $(\mathrm{kg} \text { of seed })^{-1}$. Such a value is the maximum slurry amount recommended for treating seeds with dietholate.

The variables in consideration were germination and seed vigor, as stated by Rules for Seed Testing (Brasil, 2009). The germination percentage was calculated by the quantification of normal seedlings, which corresponded to seeds germinated 12 DAS (days after sowing). The vigor was quantified through the cold test without soil, as proposed by Cicero and Vieira 
(1994). According to their methodology, before placing the paper rolls with the seeds inside a germinator at a controlled temperature, they were stowed in plastic bags and let inside a cold chamber at a controlled temperature of $10{ }^{\circ} \mathrm{C}$ for seven days. The results were quantified as aforementioned, and they were expressed as percentage of normal seedlings.

The resulting data were subjected to the ANOVA test ( $\mathrm{p} \leq 0.05)$ and, once a significant difference was detected, they were analyzed through linear regression. Additionally, the results of the seed treatment factor were compared to each other by using the orthogonal contrast method $(\mathrm{p} \leq 0.05)$.

\section{Field experiments (Experiments 2 and 3)}

The experiments 2 and 3 were conducted in the field, during the 2016/2017 harvest. They were performed according to a randomized block design, with four replications.

The cultivar IRGA 424 RI was used in a sowing density of $100 \mathrm{~kg}$. ha- ${ }^{-1}$. The seeds were planted on September $21^{\text {st }}$, 2016 , in plots dimensioned $1.53 \mathrm{~m} \times 5 \mathrm{~m}$, with a useful area of $4.8 \mathrm{~m}^{2}$, according to a minimum-cultivation system.

Table 1. Commercial products, active ingredients, and dosages used in the seed treatments (ST).

\begin{tabular}{|c|c|c|c|}
\hline Treat. & Commercial product & Active ingredients (ai.) & $\begin{array}{c}\text { Dosage } \\
\text { (g ai } 100 \text { kg.seeds }{ }^{-1} \text { ) }\end{array}$ \\
\hline $1^{1}$ & Standak top ${ }^{\circledR}$ & $\begin{array}{l}\text { Pyraclostrobin } \\
\text { Thiophanate methyl } \\
\text { Fipronil }\end{array}$ & $\begin{array}{r}3.75 \\
33.75 \\
37.50 \\
\end{array}$ \\
\hline $2^{1}$ & Standak top $^{\circledR}+$ Permit $^{\circledR}$ & $\begin{array}{l}\text { Pyraclostrobin } \\
\text { Thiophanate methyl } \\
\text { Fipronil } \\
\text { Dietholate }\end{array}$ & $\begin{array}{r}3.75 \\
33.75 \\
37.50 \\
480.00\end{array}$ \\
\hline $3^{1,2}$ & $\operatorname{Maxim} X^{\circledR}{ }^{\circledR}$ & $\begin{array}{l}\text { Fludioxonil } \\
\text { Metalaxyl-m }\end{array}$ & $\begin{array}{l}2.00 \\
5.00\end{array}$ \\
\hline $4^{1,2,3}$ & Maxim $\mathrm{XL}^{\circledR}+$ Permit $^{\mathbb{B}}$ & $\begin{array}{l}\text { Fludioxonil } \\
\text { Metalaxyl-m } \\
\text { Dietholate } \\
\end{array}$ & $\begin{array}{r}2.00 \\
5.00 \\
480.00 \\
\end{array}$ \\
\hline $5^{1}$ & Maxim $\mathrm{XL}^{\circledR}+$ Cruiser Opti $^{\circledR}$ & $\begin{array}{l}\text { Fludioxonil } \\
\text { Metalaxyl-m } \\
\text { Lambda-cyhalothrin } \\
\text { Thiamethoxam }\end{array}$ & $\begin{array}{r}2.00 \\
5.00 \\
18.75 \\
105.00 \\
\end{array}$ \\
\hline $6^{1}$ & Maxim XL ${ }^{\circledR}+$ Cruiser Opti $^{\circledR}+$ Permit $^{\circledR}$ & $\begin{array}{l}\text { Fludioxonil } \\
\text { Metalaxyl-m } \\
\text { Lambda-cyhalothrin } \\
\text { Thiamethoxam } \\
\text { Dietholate }\end{array}$ & $\begin{array}{r}2.00 \\
5.00 \\
18.75 \\
105.00 \\
480.00 \\
\end{array}$ \\
\hline $7^{1,2}$ & Vitavax-thiram $^{\circledR}$ & $\begin{array}{l}\text { Carboxin } \\
\text { Thiram }\end{array}$ & $\begin{array}{l}60.00 \\
60.00 \\
\end{array}$ \\
\hline $8^{1,2,3}$ & Vitavax-thiram $^{\circledR}+$ Permit $^{\circledR}$ & $\begin{array}{l}\text { Carboxin } \\
\text { Thiram } \\
\text { Dietholate }\end{array}$ & $\begin{array}{r}60.00 \\
60.00 \\
480.00 \\
\end{array}$ \\
\hline $9^{1}$ & Vitavax-thiram $^{\circledR}+$ Cruiser Opti $^{\circledR}$ & $\begin{array}{l}\text { Carboxin } \\
\text { Thiram } \\
\text { Lambda-cyhalothrin } \\
\text { Thiamethoxam }\end{array}$ & $\begin{array}{r}60.00 \\
60.00 \\
18.75 \\
105.00 \\
\end{array}$ \\
\hline $10^{1}$ & Vitavax-thiram $^{\circledR}+$ Cruiser Opti $^{\circledR}+$ Permit $^{\circledR}$ & $\begin{array}{l}\text { Carboxin } \\
\text { Thiram } \\
\text { Lambda-cyhalothrin } \\
\text { Thiamethoxam } \\
\text { Dietholate }\end{array}$ & $\begin{array}{r}60.00 \\
60.00 \\
18.75 \\
105.00 \\
480.00\end{array}$ \\
\hline $11^{1,2}$ & Without treatment & - & - \\
\hline
\end{tabular}

${ }^{1}$ Treatments used in experiment 1.

${ }^{2}$ Treatments used in experiment 2.

${ }^{3}$ Treatments used in experiment 3 . 
Fertilization was carried out at the moment of sowing, in a dosage of $400 \mathrm{~kg}$. ha-1 of NPK fertilizer (formulated 04-1727 ), as indicated by the soil analysis.

As for the experiment 2, the factor A tested different fungicides, chosen based on the results of the laboratory experiment, and untreated control (Table 1); whereas in factor B, the presence and absence of the plant safener dietholate (480 g ai. $100 \mathrm{~kg}$. seeds $\left.{ }^{-1}\right)$ were assessed. The treatments of this experiment did not receive the herbicide clomazone during the pre-emergence phase.

Experiment 3 employed a unifactorial scheme, including the following treatments: without fungicide and with dietholate, without fungicide but with dietholate (untreated control), and treatments four and eight selected from the first experiment (Table 1). Except for the control, the other treatments received an application of clomazone (720 g ai. ha $\left.{ }^{-1}\right)$ during the preemergence phase.

The variables considered were these: shoot dry mass (DM), emergence speed index (ESI), population (POP), and plant height (HEI). To evaluate the DM, rice plants within a $0.25 \mathrm{~m}^{2}$ area were collected 7, 14, and 21 days after emergence (DAE). The plants were cut at the soil level and then maintained inside an oven at $65^{\circ} \mathrm{C}$ until they reached a constant mass.

To establish the ESI through the equation of Popinigis (1977), the emerged seedlings within $1 \mathrm{~m}$ were counted daily until the stabilization of emergence. Seedlings were considered emerged when the shoot reached $1 \mathrm{~cm}$ long.

The features POP and HEI were assessed on the V4 stage. POP was determined by counting the seedlings within a $0.25 \mathrm{~m}^{2}$ space, and HEI by gauging ten plants per plot with a millimeter ruler. In the latter case, the measurement considered the distance from the soil surface to the apex of the highest leaf with an extended blade. The final value corresponded to the mean of the sampled plants.

The gathered data were submitted to the ANOVA test ( $\mathrm{p} \leq$ 0.05 ), and comparison-of-mean tests were performed whenever significant differences were detected among the variables. In the second experiment, the Duncan's test was applied to factor $\mathrm{A}(\mathrm{p} \leq 0.05)$, and the $\mathrm{T}$ test to factor $\mathrm{B}(\mathrm{p} \leq 0.05)$. In the third experiment, the Duncan's test was used $(\mathrm{p} \leq 0.05)$.

\section{Results and Discussion}

The analysis of variance evidenced interaction among the studied factors for both variables considered in experiment 1 (laboratory). As for experiment 2, the treatments showed interaction only for the variable DM, assessed 7 DAE. Still regarding this variable, the effect of dietholate prevailed 14 DAE. Last, in experiment 3, the treatment factors showed significance for the variables ESI and DM, evaluated 7 DAE.
Use of insecticides and fungicides in association with dietholate and the impact on germination and seed vigor (Experiment 1)

In general, the germination percentage reduced as the time interval between the seed treatment and the moment of planting increased (Figure 1). On average, such a delay lowered germination by $10 \%$ (Figure 1), which suggests that treatments should be performed right before sowing to prevent seed viability loss. Similar findings were obtained in soybean treated with insecticide and fungicide at different storage times. In this case, the active-principles might have had a phytotoxic effect on the seeds, thus compromising their germination capacity (Ludwig et al., 2011).

The application of dietholate overall affected seed germination at different levels (Figure 1). However, the most significant impact was observed in the carboxin + thiram + dietholate treatment, where the germination assessed 210 DAT was off by $20 \%$, in comparison with the control without the safener (Figure 1). On that account, it is possible to infer that the combination of dietholate and carboxin + thiram shows antagonism; thus its use should be avoided, on the risk of harming the establishment of the rice culture.

Based on the orthogonal contrast analysis, it was possible to notice that the most significant negative impact on germination was caused by the association of dietholate with fungicides (Table 2). Within this group of chemicals, the germination reduced $16 \%$ due to the association with carboxin + thiram, similarly to the previous observations. This value was higher than that of the other seed treatments, which marked decreases of $5 \%$ and $9 \%$ in the associations with pyraclostrobin + thiophanate methyl + fipronil and fludioxonil + metalaxyl-m, respectively (Table 2 ).

In a similar study with irrigated rice, seed treatments with dietholate, both in isolated form or combined with other products, negatively influenced the germination and vigor of seeds in cold temperature conditions (Rosa et al., 2017). Thus, when the germination of the untreated seeds and the dietholate-free ones was contrasted, no significant difference was observed. Nevertheless, approximately $9 \%$ germination reduction was detected among seeds treated of dietholate, in comparison with the untreated ones (Table 2). Therefore, regardless of the ST used, the application of dietholate reduced the germination of rice seeds.

When the rice seeds were subjected to the vigor test, a reduction trend was noticed whenever the treatments with fungicide and insecticide were added to seed, regardless of the active ingredient in test, while a sharper reduction happened when was added the safener dietholate to them (Figure 2). 

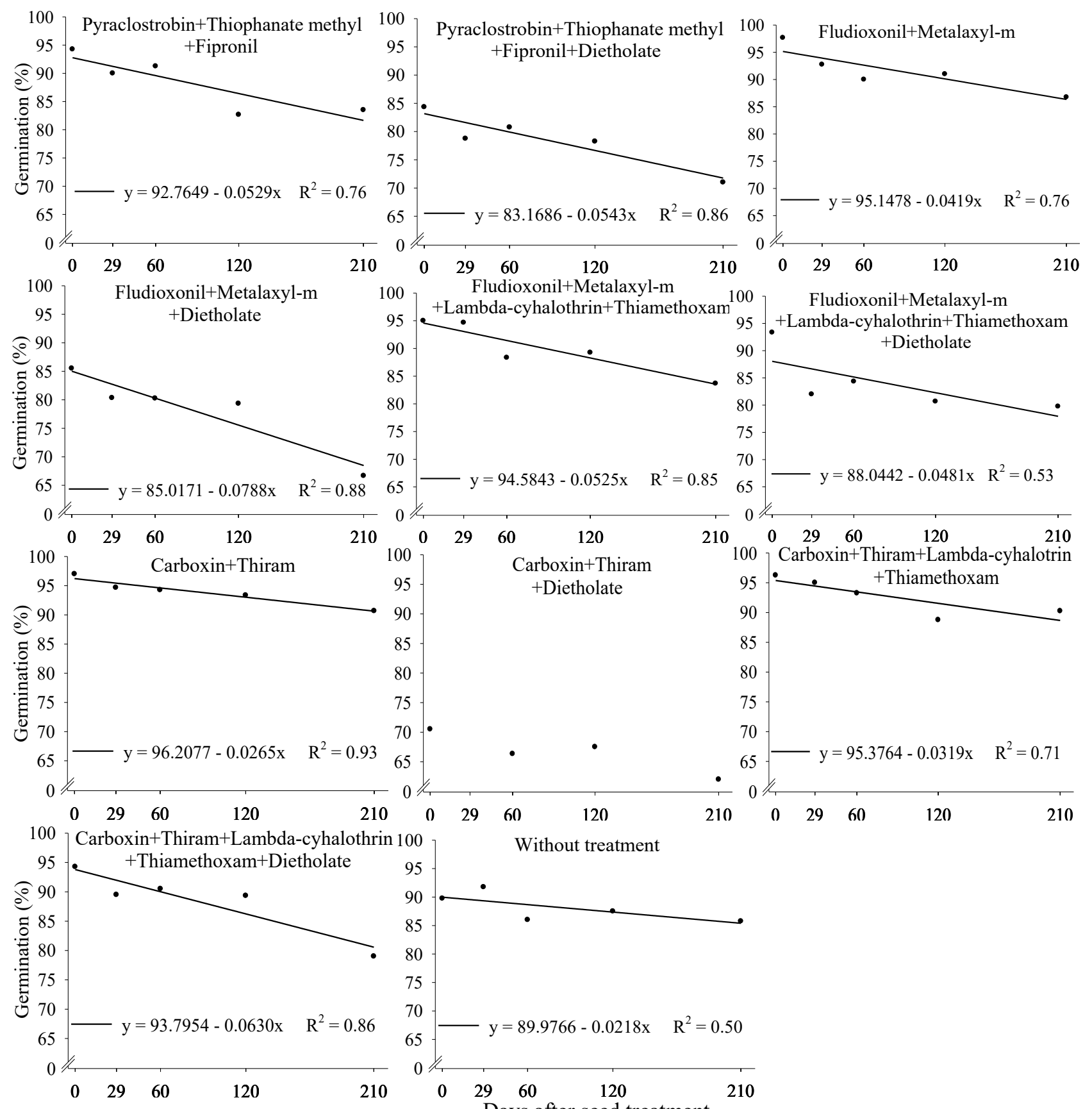

Figure 1. Germination (\%) of rice seeds (Oryza sativa L.) subjected to different treatments and sowing dates after the treatments. The dots represent the average value of each treatment.

Likewise to what happened in germination, in contrast with the untreated seeds, the association carboxin + thiram + dietholate compromised the most the vigor of seeds, with roughly $20 \%$ loss detected already at the beginning of the trials (0 DAT) (Figure 2). Also, compared to the seeds treated only with carboxin + thiram, the addition of dietholate caused the vigor to diminish around $30 \%$ within 210 DAT (Table 3 ).
This fact confirms that the association was harmful to rice seed viability, thus being considered a case of antagonism.

In a comparison between the vigor of untreated seeds and those that had received dietholate, it became evident an average reduction of $7 \%$ (Table 3), which suggests that applying the plant safener might have negatively influenced the establishment of rice. For a better growth performance, 
it is fundamental for rice plants to establishing fast and uniformly, so that they become more capable of competing for resources than the weeds (Concenço et al., 2007).

Initial establishment of irrigated rice seeds treated with dietholate (Experiments 2 and 3)

According to the field studies, the treatments containing the safener dietholate mixed with carboxin + thiram showed a significant diminution in the variable DM assessed 7 DAE, in comparison with the use of the fungicide alone (Table 4). The effect of dietholate in rice growth could still be observed $14 \mathrm{DAE}$, when the treatment with the safener, even without the application of the herbicide clomazone, decreased the DM of the shoots (Table 4). In general,
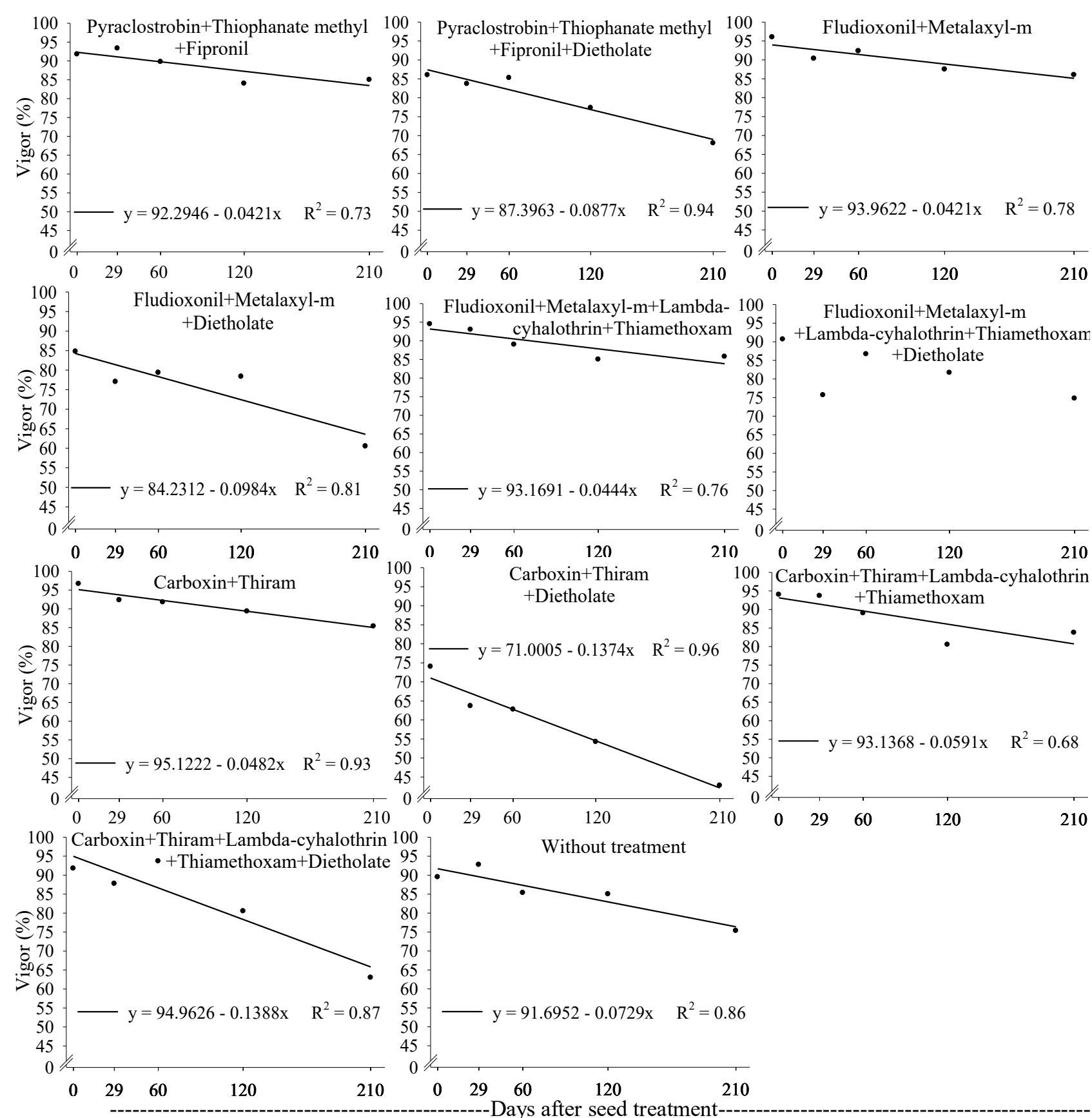

Figure 2. Vigor (\%) of rice seeds (Oryza sativa L.) subjected to different treatments and sowing dates after the treatments. Dots represent the average value of each treatment. 
Table 2. Orthogonal contrasts for germination (\%) of irrigated rice seeds (Oryza sativa L.), as a function of the different treatments with fungicide, insecticide and dietholate, and sowing times.

\begin{tabular}{|c|c|c|c|c|c|c|c|c|c|c|c|c|c|c|c|}
\hline Treatments & \multicolumn{3}{|c|}{$0 \mathrm{DAT}^{1}$} & \multicolumn{3}{|c|}{29 DAT } & \multicolumn{3}{|c|}{60 DAT } & \multicolumn{3}{|c|}{$120 \mathrm{DAT}$} & \multicolumn{3}{|c|}{210 DAT } \\
\hline Without dietholate X All & $90^{\mathrm{ns}}$ & $\mathrm{X}$ & 91 & $92 *$ & $\mathrm{X}$ & 86 & $86^{\mathrm{ns}}$ & $\mathrm{X}$ & 86 & $88 *$ & $\mathrm{X}$ & 84 & $86^{*}$ & $\mathrm{X}$ & 79 \\
\hline $\begin{array}{l}\text { Pyraclostrobin+thiophanate methyl+fipronil } \\
\text { without dietholate X Pyraclostrobin+thiophanate } \\
\text { methyl+fipronil with dietholate }\end{array}$ & $94^{\mathrm{ns}}$ & $\mathrm{X}$ & 84 & $90 *$ & $\mathrm{X}$ & 79 & $91^{*}$ & $\mathrm{X}$ & 81 & $83^{\text {ns }}$ & $\mathrm{X}$ & 78 & $84^{*}$ & $\mathrm{X}$ & 71 \\
\hline $\begin{array}{l}\text { Fludioxonil }+ \text { metalaxyl }-\mathrm{m} \text { without dietholate } \mathrm{X} \\
\text { Fludioxonil }+ \text { metalaxyl }-\mathrm{m} \text { with dietholate }\end{array}$ & $96^{*}$ & $\mathrm{X}$ & 89 & $94 *$ & $\mathrm{X}$ & 81 & $89 *$ & $\mathrm{X}$ & 82 & $90 *$ & $\mathrm{X}$ & 80 & $85^{*}$ & $\mathrm{X}$ & 74 \\
\hline $\begin{array}{l}\text { Carboxin+thiram without dietholate } \mathrm{X} \\
\text { Carboxin+thiram with dietholate }\end{array}$ & $97 *$ & $\mathrm{X}$ & 82 & $95^{*}$ & $\mathrm{X}$ & 77 & $94 *$ & $\mathrm{X}$ & 80 & $91^{*}$ & $\mathrm{X}$ & 77 & $90 *$ & $\mathrm{X}$ & 69 \\
\hline $\begin{array}{l}\text { Fungicides without dietholate } \mathrm{X} \\
\text { Fungicides with dietholate }\end{array}$ & $97 *$ & $\mathrm{X}$ & 78 & $94 *$ & $\mathrm{X}$ & 70 & $92 *$ & $\mathrm{X}$ & 74 & $92 *$ & $\mathrm{X}$ & 73 & $88 *$ & $\mathrm{X}$ & 64 \\
\hline $\begin{array}{l}\text { Insecticides+fungicides without dietholate } \mathrm{X} \\
\text { Insecticides+fungicides with dietholate }\end{array}$ & $95^{*}$ & $\mathrm{X}$ & 91 & $93 *$ & $\mathrm{X}$ & 84 & $91 *$ & $\mathrm{X}$ & 85 & $87 *$ & $\mathrm{X}$ & 82 & $86^{*}$ & $\mathrm{X}$ & 76 \\
\hline Fungicides $\mathrm{X}$ Insecticides + fungicides & $86^{*}$ & $\mathrm{X}$ & 93 & $83^{\mathrm{ns}}$ & $\mathrm{X}$ & 88 & $84^{\text {ns }}$ & $\mathrm{X}$ & 88 & $82 *$ & $\mathrm{X}$ & 85 & $76^{\mathrm{ns}}$ & $\mathrm{X}$ & 81 \\
\hline Without dietholate X With dietholate & $96^{*}$ & $\mathrm{X}$ & 85 & $93 *$ & $\mathrm{X}$ & 79 & $92 *$ & $\mathrm{X}$ & 81 & $89 *$ & $\mathrm{X}$ & 78 & $87 *$ & $\mathrm{X}$ & 72 \\
\hline Without treatment X Without dietholate & $90 *$ & $\mathrm{X}$ & 96 & $92^{\mathrm{ns}}$ & $\mathrm{X}$ & 93 & $86^{*}$ & $\mathrm{X}$ & 92 & $88^{\text {ns }}$ & $\mathrm{X}$ & 89 & $86^{\mathrm{ns}}$ & $\mathrm{X}$ & 87 \\
\hline Without treatment X With dietholate & $90^{*}$ & $\mathrm{X}$ & 85 & $92 *$ & $\mathrm{X}$ & 79 & $86^{*}$ & $\mathrm{X}$ & 81 & $88^{*}$ & $\mathrm{X}$ & 78 & $86^{*}$ & $\mathrm{X}$ & 72 \\
\hline $\mathrm{CV}(\%)$ & & 2.4 & & & 3.5 & & & 1.9 & & & 2.8 & & & 4.4 & \\
\hline
\end{tabular}

${ }^{1}$ Days after seed treatment.

* and ${ }^{\mathrm{ns}}$ significant difference and non-significant difference, respectively $(\mathrm{p} \leq 0.05)$.

Table 3. Orthogonal contrasts for the vigor (\%) of irrigated rice seeds (Oryza sativa L.), as a function of the different treatments with fungicide, insecticide and dietholate, and sowing times.

\begin{tabular}{|c|c|c|c|c|c|c|c|c|c|c|c|c|c|c|c|}
\hline Treatments & \multicolumn{3}{|c|}{$0 \mathrm{DAT}^{1}$} & \multicolumn{3}{|c|}{29 DAT } & \multicolumn{3}{|c|}{60 DAT } & \multicolumn{3}{|c|}{$120 \mathrm{DAT}$} & \multicolumn{3}{|c|}{$210 \mathrm{DAT}$} \\
\hline Without dietholate X All & $90^{\mathrm{ns}}$ & $\mathrm{X}$ & 90 & $93 *$ & $\mathrm{X}$ & 85 & $85^{\mathrm{ns}}$ & $\mathrm{X}$ & 86 & $85^{*}$ & $\mathrm{X}$ & 80 & $75^{\mathrm{ns}}$ & $\mathrm{X}$ & 74 \\
\hline $\begin{array}{l}\text { Pyraclostrobin+thiophanate methyl+fipronil } \\
\text { without dietholate X Pyraclostrobin+thiophanate } \\
\text { methyl+fipronil with dietholate }\end{array}$ & $92 *$ & $\mathrm{X}$ & 86 & $93 *$ & $X$ & 84 & $90^{*}$ & $\mathrm{X}$ & 85 & $84^{\mathrm{ns}}$ & $\mathrm{X}$ & 77 & $85^{*}$ & $\mathrm{X}$ & 68 \\
\hline $\begin{array}{l}\text { Fludioxonil }+ \text { metalaxyl }-\mathrm{m} \text { without dietholate } \mathrm{X} \\
\text { Fludioxonil }+ \text { metalaxyl }-\mathrm{m} \text { with dietholate }\end{array}$ & $95^{*}$ & $X$ & 87 & $92 *$ & $\mathrm{X}$ & 76 & $90^{*}$ & $\mathrm{X}$ & 83 & $86^{*}$ & $\mathrm{X}$ & 80 & $86^{*}$ & $X$ & 68 \\
\hline $\begin{array}{l}\text { Carboxin+thiram without dietholate X Carbox- } \\
\text { in+thiram with dietholate }\end{array}$ & $95^{*}$ & $X$ & 83 & $93 *$ & $X$ & 77 & $90 *$ & $\mathrm{X}$ & 76 & $84 *$ & $\mathrm{X}$ & 67 & $84 *$ & $X$ & 51 \\
\hline Fungicides without dietholate $\mathrm{X}$ & & & & & & & & & & & & & & & \\
\hline Fungicides with dietholate & $93^{*}$ & $X$ & 90 & $93^{*}$ & $X$ & 83 & $89 *$ & $X$ & 88 & $83^{*}$ & $X$ & 80 & $85^{*}$ & $X$ & 69 \\
\hline $\begin{array}{l}\text { Insecticides+fungicides without dietholate } \mathrm{X} \\
\text { Insecticides +fungicides with dietholate }\end{array}$ & $87 *$ & $\mathrm{X}$ & 92 & $81^{*}$ & $X$ & 88 & $81 *$ & $\mathrm{X}$ & 89 & $76^{*}$ & $\mathrm{X}$ & 82 & $68^{*}$ & $X$ & 78 \\
\hline Fungicides X Insecticides+fungicides & $94 *$ & $\mathrm{X}$ & 85 & $91 *$ & $\mathrm{X}$ & 78 & $89 *$ & $\mathrm{X}$ & 81 & $84 *$ & $\mathrm{X}$ & 74 & $83^{*}$ & $X$ & 61 \\
\hline Without dietholate X With dietholate & $90^{*}$ & $\mathrm{X}$ & 94 & $93^{\mathrm{ns}}$ & $\mathrm{X}$ & 91 & $85^{*}$ & $\mathrm{X}$ & 89 & $85^{\text {ns }}$ & $\mathrm{X}$ & 84 & $75^{*}$ & $\mathrm{X}$ & 83 \\
\hline Without treatment X Without dietholate & $90^{*}$ & $\mathrm{X}$ & 85 & $93 *$ & $\mathrm{X}$ & 78 & $85^{*}$ & $\mathrm{X}$ & 81 & $85^{*}$ & $\mathrm{X}$ & 74 & $75^{*}$ & $\mathrm{X}$ & 61 \\
\hline Without treatment X With dietholate & $92 *$ & $\mathrm{X}$ & 86 & $93 *$ & $X$ & 84 & $90^{*}$ & $\mathrm{X}$ & 85 & $84^{\mathrm{ns}}$ & $\mathrm{X}$ & 77 & $85^{*}$ & $\mathrm{X}$ & 68 \\
\hline CV $(\%)$ & & 1.75 & & & 2.47 & & & 3.38 & & & 4.38 & & & .56 & \\
\hline
\end{tabular}

${ }^{1}$ Days after seed treatment.

* and ${ }^{n s}$ significant difference and non-significant difference, respectively $(\mathrm{p} \leq 0.05)$. 
Table 4. Effect of the seed treatments with fungicide and dietholate on the shoot dry mass (DM, $\left.\mathrm{g} 0,25 \mathrm{~m}^{-2}\right)$ of irrigated rice plants (Oryza sativa L.), assessed 7, 14, and 21 days after emergence (DAE).

\begin{tabular}{|c|c|c|c|c|c|c|}
\hline \multirow{3}{*}{ Seed treatments $(\mathrm{ST})$} & \multicolumn{2}{|c|}{ DM 7 DAE } & \multicolumn{2}{|c|}{ DM 14 DAE } & \multicolumn{2}{|c|}{ DM 21 DAE } \\
\hline & \multicolumn{6}{|c|}{ Dietholate } \\
\hline & With & Without & With & Without & With & Without \\
\hline Control & $0.34 \mathrm{Aa}^{1}$ & $0.43 \mathrm{Aa}$ & $1.42^{\mathrm{ns}}$ & 1.83 & $4.49^{\mathrm{ns}}$ & 5.12 \\
\hline Metalaxyl & $0.39 \mathrm{Aa}$ & $0.44 \mathrm{Aa}$ & 1.53 & 1.96 & 4.80 & 4.85 \\
\hline Carboxin + Thiram & $0.28 \mathrm{Ab}$ & $0.67 \mathrm{Aa}$ & 0.71 & 1.91 & 4.73 & 3.86 \\
\hline \multicolumn{7}{|c|}{ Effects of the treatment factors } \\
\hline Dietholate & $0.34 \mathrm{~b}$ & $0.51 \mathrm{~A}$ & $1.22 \mathrm{~b}$ & $1.90 \mathrm{a}$ & $4.67^{\mathrm{ns}}$ & 4.61 \\
\hline Control & \multicolumn{2}{|c|}{$0.39^{\mathrm{ns}}$} & \multicolumn{2}{|c|}{$1.62^{\mathrm{ns}}$} & \multicolumn{2}{|c|}{$4.81^{\mathrm{ns}}$} \\
\hline Metalaxyl & \multicolumn{2}{|c|}{0.42} & \multicolumn{2}{|c|}{1.74} & \multicolumn{2}{|c|}{4.83} \\
\hline Carboxin + Thiram & \multicolumn{2}{|c|}{0.48} & \multicolumn{2}{|c|}{1.31} & \multicolumn{2}{|c|}{4.30} \\
\hline $\mathrm{CV}(\%)$ & \multicolumn{2}{|c|}{26.05} & \multicolumn{2}{|c|}{32.59} & \multicolumn{2}{|c|}{32.44} \\
\hline
\end{tabular}

${ }^{1}$ Means followed by distinct uppercase letters, in the column, and lowercase letters, in the row, indicate a significant difference, according to Duncan's and T tests $(\mathrm{p} \leq 0.05)$.

${ }^{\mathrm{ns}}$ no significant difference was observed, according to the $\mathrm{F}$ test $(\mathrm{p} \leq 0.05)$.

although dietholate initially affected the establishment of rice plants, such damage did not endure, once its effect was not remarked 21 DAE. A similar outcome was found in a study with three cultivars of beans. In this case, the application of higher dosages of dietholate, even without the joint use of clomazone, produced an adverse effect on the accumulation of DM in plant shoot (Takano et al., 2012).

The main effect of the dietholate use came from the interaction with other products, as evidenced by the treatment without fungicide + dietholate, in which the ESI observed was higher than that of treatments with associated fungicides (Table 5). This result corroborates the laboratory experiment findings, according to which no significant difference was noticed in vigor, nor the dietholate application posed harm to the seeds (Table 3). In this sense, despite the lower ESI of the treatment without fungicide + dietholate that did not receive clomazone, the DM assessed 21 DAE was superior to the other treatments, thus evidencing the phytotoxic effect of this herbicide at high dosages, even when the plant safener was also present (Table 5).

Results of the effect of dietholate in rice seed treatment showed a significant reduction in the ESI values when seeds also received the plant safener. In these cases, coating the seeds might have decelerated water absorption and, consequently, provoked alterations in metabolic e biochemical processes required for germination and emergence (Mistura et al., 2008). The outcomes of the present work suggest that the association between fungicides and the safener dietholate might influence in early phases of rice development. Therefore, it is worth remarking that treating rice seeds with dietholate can affect the establishment of the culture due to adverse effects from its interaction with certain fungicides.
Table 5. Effect of the seed treatments with fungicide and dietholate, in association with the pre-emergence application of clomazone, on the emergence speed index (ESI) and shoot dry mass (DM, g $0.25 \mathrm{~m}^{-2}$ ) of irrigated rice plants (Oryza sativa L.), assessed 7,14 , and 21 days after emergence (DAE).

\begin{tabular}{lcccc}
\hline Treatment & ESI & DM 7 & DM 14 & DM 21 \\
\hline $\begin{array}{l}\text { Without fungicide }+ \\
\text { dietholate }\end{array}$ & $23.04 \mathrm{a}^{2}$ & $0.45^{\mathrm{ns}}$ & $1.39^{\mathrm{ns}}$ & $4.01 \mathrm{~b}$ \\
$\begin{array}{l}\text { Without fungicide }+ \\
\text { dietholate }\end{array}$ & $13.14 \mathrm{~b}$ & 0.55 & 1.43 & $5.31 \mathrm{a}$ \\
$\begin{array}{l}\text { Metalaxyl + dietholate } \\
\begin{array}{l}\text { Carboxin + Thiram }+ \\
\text { dietholate }\end{array}\end{array}$ & $17.06 \mathrm{~b}$ & 0.72 & 1.65 & $3.85 \mathrm{~b}$ \\
\hline CV $(\%)$ & $19.23 \mathrm{~b}$ & 0.61 & 1.32 & $3.30 \mathrm{~b}$ \\
\hline
\end{tabular}

${ }^{1}$ Treatment did not receive the herbicide clomazone dosage of $720 \mathrm{~g}$ ai ha ${ }^{-1}$

${ }^{2}$ Means followed by distinct letters in the column indicate a significant difference, according to the Duncan's test $(\mathrm{p} \leq 0.05)$.

${ }^{n s}$ no significant difference was observed, according to the $\mathrm{F}$ test $(\mathrm{p} \leq 0.05)$.

\section{Conclusions}

Using the safener dietholate in association with the seed treatments carboxin + thiram, pyraclostrobin + thiophanate methyl + fipronil, or fludioxonil + metalaxyl $-\mathrm{m}$ exhibits antagonism with germination and vigor of irrigated rice seeds.

Adding dietholate to fungicide-insecticide treatments reduces the germination and vigor of rice seeds. 


\section{References}

BRASIL. Ministério da Agricultura, Pecuária e Abastecimento. Regras para análise de Sementes. Ministério da Agricultura, Pecuária e Abastecimento. Secretaria de Defesa Agropecuária. Brasília: MAPA/ACS, 2009. 365p.http://www.agricultura.gov.br/assuntos/ insumos-agropecuarios/arquivos-publicacoes-insumos/2946_ regras_analise_sementes.pdf

CICERO, S.M.; VIEIRA, R.D. Teste de frio. In: VIEIRA, R.D.; CARVALHO, N.M. (Ed.) Testes de vigor em sementes. Jaboticabal: FUNEP, 1994. p.151-164.

CONAB. Levantamento de safra: $12^{\circ}$ Levantamento de grãos safra 2016/17. http://www.conab.gov.br/OlalaCMS/uploads/ arquivos/17_09_12_10_14_36_boletim_graos_setembro_2017. pdf Accessed on Oct $8^{\text {th }}, 2017$.

CONCENÇO, G.; LOPES, N.F.; ANDRES, A.; SANTOS, M.Q.; RIEFFEL FILHO, J.A.; GARCIA, C.A.N. Emergência e crescimento inicial de plantas de arroz e capim-arroz. Planta Daninha, v.25, n.3, p.457-463, 2007. http://www.scielo.br/pdf/pd/v25n3/04.pdf

EPAGRI. Empresa de Pesquisa Agropecuária e Extensão Rural de Santa Catarina. Síntese Anual da Agricultura de Santa Catarina 2016 - 2017. http://docweb.epagri.sc.gov.br/website_cepa/publicacoes/ Sintese_2016.pdf Accessed on Dec 12 $2^{\text {th }}, 2017$.

FERHATOGLU, Y.; AVDIUSHKO, S.; BARRET, M. The basic for safening of clomazone by phorate insecticide in cotton and inhibitors of cytochrome P450s. Pesticide Biochemistry and Physiology, v.81, p.59-70, 2005. https://ac.els-cdn.com/S0048357504001099/1-s2.0S0048357504001099-main.pdf?_tid=2f517270-04e0-11e8-a39c00000aab0f26\&acdnat $=1517222343 \_1 \mathrm{cc} 17842 \mathrm{e} 6 \mathrm{~b} 8 \mathrm{f} 558 \mathrm{c} 69 \mathrm{bafea}$ $2 \mathrm{f} 964373$

FERHATOGLU, Y.; BARRET, M. Studies of clomazone mode of action. Pesticide Biochemistry and Physiology, v.85, n.1, p.7-14, 2006. https:// ac.els-cdn.com/S0048357505001288/1-s2.0-S0048357505001288main.pdf? tid=86caaedc-04df-11e8-9fca-00000aab0f01\&acdnat $=1517$ 222052_14920770f190356a2ed7276663d7dad8

HEAP, I. International Survey of Herbicide Resistant Weeds 2017. http:// weedscience.org/Summary/Country.aspx?CountryID $=5 \&$ gtAccessed on Apr $26^{\text {th }}, 2017$.

IRGA. Instituto Rio Grandense do Arroz. Boletim de resultados da lavoura de arroz safra 2017/18. https://irga-admin.rs.gov.br/upload/ arquivos/201807/30100758-boletim-final-da-safra-201-18-final.pdf Accessed on Dec $21^{\text {th }}, 2018$.

LUDWIG, M.P.; LUCCA FILHO, O.; BAUDET, L.L.; DUTRA, L.M.C.; AVELAR, S.A.G.; CRIZEL, R.L.C. Qualidade de sementes de soja armazenada após recobrimento com aminoácido, polímero, fungicida e inseticida. Revista Brasileira de Sementes, v.33, n.3, p.395-406, 2011.http://www.scielo.br/pdf/rbs/v33n3/02.pdf
MENTEN, J.O.M. Tratamento de sementes. In: SOAVE, J.; OLIVEIRA, M.R.M.; MENTEN, J.O.M. (Ed.). Tratamento químico de sementes. In: SIMPÓSIO BRASILEIRO DE PATOLOGIA DE SEMENTES, 4, Gramado, 1996. Anais. Campinas: Fundação Cargill, 1996. p.3-23.

MENTEN, J.O.M.; MORAES, M.H.D. Tratamento de sementes: histórico, tipos, características e benefícios. Informativo ABRATES, v.20, n.3, p.52-71, 2010. http://www.abrates.org.br/images/stories/ informativos/v20n3/minicurso03.pdf. Accessed on Sep 9 $9^{\text {th }}, 2017$.

MISTURA, C.C.; BRANCO, J.C.; FREITAS, D.C.; ROSENTHAL, M.D.; MORAES, D.M.; OLIVEIRA, A.C.; Influência do protetor de sementes dietilfenilfosforotioato sobre plântulas de arroz (Oryza sativa L.).Revista Brasileira de Agrociência, v.14, p.231-238, 2008.https://periodicos.ufpel.edu.br/ojs2/index.php/CAST/article/ viewFile/1906/1739

OLIVEIRA JUNIOR, R.S.; INOUE, M.H. Seletividade de herbicidas para culturas e plantas daninhas. In: OLIVEIRA JUNIOR, R.S.;CONSTANTIN, J.; INOUE, M.H. (Ed.). Biologia e manejo de plantas daninhas. Curitiba, PR: Omnipax, 2011. p.243-262.

POPINIGIS, F. Fisiologia da semente. Brasília : AGIPLAN, 1977. 289p.

ROSA, T.D.; HELGUEIRA, D.B.; ALMEIDA, S.A.; SOARES, N.S.; MATTOS, F.P.; MEDEIROS, D.C. Vigor de sementes de arroz irrigado tratadas com dietholate isolado e em combinação em duas temperaturas. Revista Tecnologia e Ciência Agropecuária, v.11, n.2, p.59-62, 2017. http://revistatca.pb.gov.br/edicoes/volume-11-2017/ v-11-n-2-junho-2017/tca11211.pdf

SENSEMAN, S.A. Herbicide handbook.9.ed. Lawrence: Weed Science Society of America, 2007. 458p.

SHERDER, E.F.; TALBERT, R.E.; CLARK, S.D. Rice (Oryza sativa) cultivar tolerance to clomazone. Weed Technology, v.18, n.1, p.140144, 2004. http://www.bioone.org/doi/pdf/10.1614/WT-03-063

SOSBAI. Sociedade Sul-Brasileira de Arroz Irrigado. Arroz irrigado: recomendações técnicas da pesquisa para o Sul do Brasil. XXXI Reunião Técnica da Cultura do Arroz Irrigado, Bento Gonçalves, 2016. 200p.

TAKANO, H.K.; OLIVEIRA JUNIOR, R.S.; CONSTANTIN, J.; OLIVEIRA NETO, A.M.; BRAZ, G.B.P.; DAN, H.A.; GUERRA, N.; RIOS, F.A. Potencial de utilização do dietholate como protetor de clomazone em feijoeiro comum. Revista Brasileira de Herbicidas, v.11, n.3, p.305-315, 2012.http://www.rbherbicidas.com.br/index. $\mathrm{php} / \mathrm{rbh} /$ article/view/197/pdf

YUN, M.S.; YOGO, M.Y.Y.; MIURA, R.; YAMASUE, Y.; FISCHER, A.J. Cytochrome P-450 monooxygenase activity in herbicide-resistant and susceptible late watergrass (Echinochloa phyllopogon). Pesticide Biochemistry and Physiology, v.83, n.2, p.107-114, 2005.https:// ac.els-cdn.com/S0048357505000544/1-s2.0-S0048357505000544main.pdf? tid $=62 \mathrm{e} 187 \mathrm{fe}-04 \mathrm{e} 2-11 \mathrm{e} 8-\mathrm{b} 5 \mathrm{e} 5-00000 \mathrm{aab} 0 \mathrm{f} 02 \& \mathrm{acdnat}=15$ $17223280 \_$2e3215679f0664156ef42bef90109d3e 